\title{
Selection of resistance sources to common bean anthracnose by field phenotyping and DNA marker-assisted screening
}

\author{
A.F. Vieira ${ }^{1}$, L.C.S. Almeida ${ }^{1}$, L.A. Rodrigues ${ }^{2}$, J.G.C. Costa ${ }^{2}$, \\ L.C. Melo ${ }^{2}$, H.S. Pereira ${ }^{2}$, D.A. Sanglard ${ }^{3}$ and T.L.P.O. Souza ${ }^{2}$ \\ ${ }^{1}$ Universidade Federal de Goiás (UFG), 74.690-900, Goiânia, GO, Brasil \\ ${ }^{2}$ Embrapa Arroz e Feijão, 75.375-000, Santo Antônio de Goiás, GO, Brasil \\ ${ }^{3}$ Universidade Federal de Minas Gerais (UFMG), 39.404-547, Montes \\ Claros, MG, Brasil
}

Corresponding author: T.L.P.O. Souza

E-mail: thiago.souza@embrapa.br

Genet. Mol. Res. 17 (3): gmr18066

Received June 25, 2018

Accepted August 07, 2018

Published August 27, 2018

DOI http://dx.doi.org/10.4238/gmr18066

\begin{abstract}
The main goal of this work was to select resistance sources to common bean anthracnose by field phenotyping and DNA marker-assisted screening. Fifty-five common bean genotypes, including differential varieties, characterized resistance sources, elite lines, cultivars and controls, were evaluated in a field inoculation trial and screened with SCAR markers linked to resistance genes that are important in Brazil. The field trial was carried out in Santo Antônio de Goiás, GO, Brazil, during the fall/winter growing season of 2014, using artificial inoculation with a mixture of six races of Colletotrichum lindemuthianum, selected based on their high virulence and prevalence in Brazil. Amplification reactions with the SCAR markers previously identified as linked to important anthracnose resistance genes on Brazil followed standard procedures. Twenty-eight of the 58 genotypes were resistant to anthracnose (mean severity score $\leq 3.5$ ). Ten of these 28 resistant genotypes stood out because they presented a mean anthracnose severity score of 1.0. Four of the six SCAR markers tested shown to be useful for the assisted selection of their respective target genes (SH18 and SAS13 for $\mathrm{Co}_{-} \mathbf{4}^{2}, \mathrm{SAB} 03$ for $\mathrm{Co}-5$, and SAZ20 for $\mathrm{Co}-6$ ). Two carioca seeded elite lines were highlighted by the phenotypic and molecular
\end{abstract}


screening: $\mathrm{K} 10\left(\mathrm{Co}^{-} 3^{4}, \mathrm{Co}-4^{2}, \mathrm{Co}-5\right.$ and $\left.\mathrm{Co}-6\right)$ and $\mathrm{K} 13\left(\mathrm{Co}-4^{2}\right)$. The phenotypic and molecular characterization of candidate resistance sources to common bean anthracnose based on their disease reaction in field inoculation trials and on the analysis with molecular markers linked to resistance genes has shown to be a useful strategy. These results aid in the selection of donor parents and resistant lines to be preferably explored by common bean breeding programs in Brazil.

Key words: Colletotrichum lindemuthianum; Phaseolus vulgaris; Molecular markers; Parent selection; Plant breeding

\section{INTRODUCTION}

The common bean (Phaseolus vulgaris L.) is one of the main sources of vegetable protein used worldwide. It is widely grown and consumed in most countries from Latin American and African, in different regions and growing seasons (Broughton et al., 2003; Food and Agriculture Organization - http://faostat.fao.org). In Brazil, it is a legume grain grown by smallholder farmers, mainly for their subsistence, and by rural companies, which use a high level of technology for bean production. However, the national mean yield is low (around 1,450 kg/ha) when compared to the yield potential of the crop, which is over 4,000 $\mathrm{kg} / \mathrm{ha}$ (Del Peloso and Melo, 2005, Embrapa Arroz e Feijão, 2018). One explanation for this fact is the large number of diseases that affect the common bean crop, including anthracnose caused by the fungus Colletotrichum lindemuthianum (Sacc. and Magnus) Briosi and Cavara (Paula-Júnior and Zambolim, 1998). High relative humidity and moderate temperatures between $13-26^{\circ} \mathrm{C}$ favor the occurrence of this disease, which can cause losses of up to $100 \%$ in areas where favorable conditions for this fungus are predominant and when susceptible cultivars with infected seeds are used (Singh and Schwartz, 2010).

Among the measures for integrated management of anthracnose, the use of resistant cultivars is highlighted because it is an efficient, safe and accessible strategy for growers using various different technological levels (Kelly et al., 2003; Singh and Schwartz, 2010). However, the wide variability of $C$. lindemuthianum is a challenge for the common bean breeders. In Brazil, dozens of physiological races of the anthracnose pathogen have already been identified and described (Rava et al., 1994; Balardin et al., 1997; Carbonell et al., 1999; Alzate-Marin and Sartorato, 2004; Ribeiro et al., 2016). Genetic and physiological diversity have also been reported among $C$. lindemuthianum isolates belonging to the same race (Davide et al., 2009; Ishikawa et al., 2011). For this reason, the identification of new anthracnose resistance sources and multi-site validation of the main identified sources are frequent components of common bean breeding programs aiming to develop cultivars with broad and durable resistance to anthracnose.

In general, anthracnose resistance in common bean is monogenic and dominant, i.e., controlled by major genes with simple inheritance (Kelly and Vallejo, 2004; GonçalvesVidigal and Kelly, 2006, Gonçalves-Vidigal et al., 2009; Oblessuc et al., 2015). However, it can also be oligogenic, controlled by independent dominant genes (Campa et al., 2009), complementary genes with epistatic interaction (Muhalet et al., 1981; Alzate-Marin et al., 1997), or by multiple minor genes with secondary effects (Vallejo and Kelly, 2009; Zuiderveen et al., 2016). Alzate-Marin et al. (1997) also report a simple recessive gene (co- 
8) that controls resistance to anthracnose in the common bean line AB 136. Currently, 14 anthracnose resistance loci have been characterized and reported. They are named according to the nomenclature proposed by Kelly and Young (1996): Co- 1 to Co-17, excluding Co-7, Co-9 and Co-10, which have been renamed, as well as others that follow a different standard of nomenclature, such as Co-u, Co-v, Co-w, Co- $x, \mathrm{Co}-y$ and $\mathrm{Co}-z$ (Geffroy et al., 2008). Allelic series were identified for four of these loci: $\mathrm{Co}-1, \mathrm{Co}-3, \mathrm{Co}-4$ and $\mathrm{Co}-5$. It has been demonstrated that the genes $\mathrm{Co}-7$ and $\mathrm{Co}-9$ (renamed as $\mathrm{Co}-3^{3}$ ) and $\mathrm{Co}-\mathrm{CO}$ (renamed as $\mathrm{Co}^{-3^{4}}$ ) are indeed allelic to $\mathrm{Co}-3$ (Méndez-Vigo et al., 2005; Rodríguez-Soárez et al., 2008; Gonçalvez-Vidigal et al., 2013). Genes Co-1, Co-12 and Co-13 are from Andean gene pool, being the others of Mesoamerican origin. The mapped resistance loci are distributed in eight of the 11 common bean chromosomes: Pv01, Pv02, Pv03, Pv04, Pv07, Pv08, Pv09 and Pv11 (Bean Improvement Cooperative, 2018).

There are several molecular markers available for the assisted selection of resistance genes to common bean diseases, mainly for anthracnose. Many of them are Sequence Characterized Amplified Region (SCAR) markers (Bean Improvement Cooperative, 2018). Molecular screening of common bean genotypes with these markers has been used as a strategy for the indirect selection of potential sources of anthracnose resistance genes, i.e., molecular markers are being used as an additional tool to identify the presence or absence of anthracnose resistance alleles in common bean genotypes (Souza et al., 2005; Beraldo et al., 2009).

The main goal of the present work was to evaluate candidate common bean anthracnose resistance sources based on their reaction to the disease in a field inoculation trial and through molecular screening with SCAR markers identified as linked to resistance genes important in Brazil. This will allow selecting resistance sources to be preferably exploited as donor parents by common bean breeding programs in Brazil.

\section{MATERIAL AND METHODS}

Fifty-four candidate common bean resistance sources to anthracnose were evaluated, including international differential varieties, sources of already characterized resistance genes, elite lines and cultivars developed by Embrapa (Brazilian Agricultural Research Corporation), in addition to the susceptible control Rosinha G2. Seeds of all these genotypes were obtained from the work collection of the Embrapa common bean breeding program.

The field trial to screen the common bean genotypes for reaction to anthracnose was carried out at Embrapa Arroz e Feijão (Santo Antônio de Goiás, GO, Brazil), during the fall/winter growing season of 2014, using a randomized complete block design, with three replicates. Each plot consisted of two 3.0-m long rows, with $0.5 \mathrm{~m}$ between rows. Fifteen days after seedling emergence, at phenological stage V3, all plants in each plot were inoculated with a mixture of six races of $C$. lindemuthianum: 65 (isolate Cl_1614), 73 (isolate Cl_1143), 81 (isolate $\mathrm{Cl} \_1164$ ), 91 (isolate $\mathrm{Cl} \_1247$ isolate), 475 (isolate $\mathrm{Cl} \_1322$ ) and 1609 (isolate Cl_1294). Selection of these races was based on the following criteria: prevalence in Brazil (races 65, 73, 81 and 91) and high virulence (races 475 and 1609), in addition to sporulation capacity in a controlled environment.

Inoculum preparation was as described by Pastor-Corrales et al. (1995), but with some modifications. Inoculum production was carried out in the laboratory by 
streaking the fungus in test tubes containing a sterilized common bean pod partially immersed in agar-water medium. The inoculum suspension with final concentration adjusted to $1.2 \times 10^{6}$ conidia/mL was sprayed on all plants of each plot with the aid of a $20 \mathrm{~L}$ portable sprayer. About $200 \mathrm{~mL}$ of inoculum suspension was sprayed per plot of $1.5 \mathrm{~m}^{2}$. Evaluation of anthracnose symptoms was performed in two stages, by two evaluators, at 15 and 30 days after inoculation, using a nine degrees severity scale, where $1=$ plot with plants showing no disease symptoms, and $9=$ plot with $100 \%$ of infected or dead plants (Melo, 2009). The anthracnose severity data were submitted to analysis of variance. The mean severity scores were compared by the Scott and Knott method at 5\% probability using the Genes program (Cruz, 2013). Genotypes with mean scores $\leq 3.5$ were considered resistant, while those with mean scores $>3.5$ were considered as susceptible.

Leaf tissue samples from each tested common bean genotypes were collected in bulk, sampling 10 individual plants from each genotype, and stored in an ultra-freezer at $-20^{\circ} \mathrm{C}$. DNA extraction was performed using the CTAB method, as described by Ferreira and Grattapaglia (1998). DNA samples from all genotypes were then amplified using SCAR markers identified as linked to anthracnose resistance genes important in Brazil, which are described in Table 1. Amplification reactions were performed via PCR with final volume of $15.0 \mu \mathrm{L}$, using the commercial kit Master Mix (Qiagen Multiplex PCR Kit). Each reaction consisted of $30 \mathrm{ng}$ of DNA, 5.0 $\mu \mathrm{L}$ of Master Mix, $0.5 \mu \mathrm{L}$ of Q-solution, and $1.0 \mu \mathrm{L}$ of each specific primers (forward and reverse) at the concentration of $10.0 \mu \mathrm{M}$ (Table 1). PCR reactions were performed using the following conditions: i) a first stage of $95^{\circ} \mathrm{C}$ for 5 minutes; ii) forty cycles of amplification including an initial denaturation step at $95^{\circ} \mathrm{C}$ for 15 seconds, a second annealing step of primers to the template DNA ranging from $54-$ to $-72^{\circ} \mathrm{C}$ (Table 1) for 90 seconds, and a third extension step at $72^{\circ} \mathrm{C}$ for 1 minute; and a final extension stage of $72^{\circ} \mathrm{C}$ for 10 minutes.

Table 1. Sequence characterized amplified region (SCAR) markers linked to anthracnose resistance genes in common bean, with the gene identification or official symbol, resistance source, genome location, primer sequences and annealing temperature of primers.

\begin{tabular}{lcccclc}
\hline Marker $^{\mathbf{a}}$ & Gene & Source & Chromosome & Distance $(\mathbf{c M})$ & \multicolumn{1}{c}{ Primer sequence } & T $\left({ }^{\circ} \mathbf{C}\right)$ \\
\hline SF10 & Co-3 & Ouro Negro & Pv04 & 12.3 & $\begin{array}{l}\text { F: GGAAGCTTGGTGAGCAAGGA } \\
\text { R: GGAAGCTTGGCTATGATGGT }\end{array}$ & 65 \\
SY20 & Co-4 & TO & Pv08 & 0.0 & $\begin{array}{l}\text { F: AGCCGTGGAAGGTTGTCAT } \\
\text { R: CAGAGACCCTAGGCTTATCG }\end{array}$ & 60 \\
SAS13 & Co-4 $4^{2}$ & SEL1308 & Pv08 & 0.4 & $\begin{array}{l}\text { F: CACGGACCGATAAGCCACCAACA } \\
\text { R: CACGGACCGAGGATACAGTGAAAG }\end{array}$ & 72 \\
SH18 & Co-4 & SEL1308 & Pv08 & 4.2 & $\begin{array}{l}\text { F: CCAGAAGGAGCTGATAGTAGTCCACAAC } \\
\text { R: GGTAGGCACACTGATGAATCTCATGTTGGG }\end{array}$ & 60 \\
SAB03 & Co-5 & TU & Pv07 & 5.9 & $\begin{array}{l}\text { F: TGGCGCACACATAAGTTCTCACGG } \\
\text { R: TGGCGCACACCATCAAAAAAGGTT }\end{array}$ & 54 \\
SAZ20 & Co-6 & AB136 & Pv07 & 7.1 & $\begin{array}{l}\text { F: ACCCCTCATGCAGGTTTTA } \\
\text { R: CATAATCCATTCATGCTCACC }\end{array}$ & 60 \\
\hline
\end{tabular}

${ }^{\mathrm{a}}$ Source: Bean Improvement Cooperative (2018). 
For the electrophoresis analysis, $3.0 \mu \mathrm{L}$ of bromophenol blue dye were added to the amplification products, which were submitted to a $1.5 \%$ agarose gel electrophoresis in $1 \mathrm{X}$ TBE (Tris-boric acid/EDTA) at 100 volts for $2 \mathrm{~h}$. For analysis of the DNA amplification products, the agarose gel was stained in ethidium bromide solution for 20 minutes and then visualized under UV light. Gel images were photo-digitalized and the amplified DNA products interpreted as present (1) or absent (0). The size of DNA fragments was measured by comparison to a $1 \mathrm{~kb}$ DNA ladder (Qiagen GelPilot Ladder).

\section{RESULTS AND DISCUSSION}

The results of the analysis of variance (Table 2) showed the existence of genetic variability for anthracnose severity among the common bean genotypes tested, which were grouped based on their average severity score, according to the Scott-Knott method (Table $3)$. Twenty-eight of the 55 genotypes tested in the field inoculation trial were resistant to anthracnose (mean severity score $\leq 3.5$ ), represented by the genotypes that formed the "a", "b" and "c" groups in Table 3. Ten of these 28 resistant genotypes stood out because they presented a mean severity score of 1.0: BRS Esteio ( $\mathrm{Co}-$ ?), BRSMG Realce (Co-?), BRS Sublime (Co-?), CNFC 10729 (Co-?), Ouro Negro (Co-34), K10 (Co-4 ${ }^{2}, \mathrm{Co}^{4} 3^{4}, \mathrm{Co}-5$ and Co-6), K13 $\left(\mathrm{Co}_{-}^{2}\right)$, SEL $1308\left(\mathrm{Co}-4^{2}\right)$, TO $(\mathrm{Co}-4)$ and AB $136(\mathrm{Co}-6$ and $\mathrm{co}-8)$ (Table 3). Among the 55 common bean genotypes that were phenotypically characterized, 27 were susceptible to anthracnose (mean severity score > 3.5), represented by the genotypes on "d", "e" and "f" groups in Table 3. These susceptible groups include the current international differential varieties for anthracnose Cornell 49-242 (Co-2) and Michelite (Co-11), in addition to known resistance sources such as BAT $93\left(\mathrm{Co}^{3} 3^{3}\right), \mathrm{H} 1\left(\mathrm{Co}^{-} 3^{5}\right)$, and SEL 1360 $\left(C o-5^{2}\right)$. As expected, the susceptible control Rosinha G2 presented the highest mean severity score (9.0) (Table 3).

Table 2. Summary of analysis of variance for anthracnose severity in common bean genotypes tested in a field inoculation trial carried out in Santo Antônio de Goiás, GO, Brazil, during the fall/winter growing season of 2014.

\begin{tabular}{|c|c|c|c|c|c|}
\hline Source of variation & df & Sum of squares & Mean square & $F$-value & $P$-value \\
\hline Block & 2 & 0.11 & 0.055 & 0.31 & 0.7367 \\
\hline Genotype & 54 & $1,094.45$ & 20.268 & 113.86 & 0.0001 \\
\hline Residue & 108 & 19.22 & 0.178 & & \\
\hline Total & 164 & $1,113.78$ & & & \\
\hline $\begin{array}{l}\mathrm{CV}=10.6 \% \\
\text { Accuracy }=99.6 \%\end{array}$ & & & & & \\
\hline
\end{tabular}

Based on the results from this work, and as previously reported by Souza et al. (2005) and Beraldo et al. (2009), it we can see that the Brazilian common bean breeding programs have good resistance sources to anthracnose to use as donor parents. In addition, these programs are also being efficient in the development of elite lines and cultivars resistant to anthracnose. However, considering the wide variability and rapid emergence of new C. lindemuthianum races in Brazil (Alzate-Marin and Sartorato, 2004; Ribeiro et al., 2016), resistance to anthracnose should always be considered in the selection process of superior genotypes, since several cultivars also presented high disease mean severity scores (Table 3). 
In the molecular characterization of the common bean lines and cultivars, the SCAR markers SH18 $\left(\mathrm{Co}_{-} 4^{2}\right)$, SAS $13\left(\mathrm{Co}-4^{2}\right)$, SAB03 $(\mathrm{Co}-5)$ and SAZ2O (Co-6) were specific for the loci to which they are linked, under the amplification conditions described here. However, these markers were not allele-specific. Only the SH18 marker was able to discriminate the $\mathrm{Co}_{-} 4^{2}$ allele from the $\mathrm{Co}-4$ e $\mathrm{Co}^{-} 4^{3}$ alleles (Table 3). Awale and Kelly (2001) developed the SH18 marker linked to the $\mathrm{Co}-4^{2}$ allele and had previously reported that this marker is specific for this allele.

Of the 55 common bean genotypes tested with the molecular markers, 31 presented the SF10 marker, including cultivars, elite lines and controls, independent of the presence of alleles of the locus $\mathrm{Co}-3$, indicating the non-specificity of this marker. SF10 amplified DNA fragments for Mexico $222(\mathrm{Co}-3)$ and Ouro Negro $\left(\mathrm{Co}^{-} 3^{4}\right)$, as expected, but also for TU (Co-5) and AB136 (Co-6 and co-8), as well as for other genotypes with known genes or resistance alleles, such as Kaboon $\left(\mathrm{Co}^{2} \mathrm{I}^{2}\right)$, Perry Marrow $\left(\mathrm{Co}^{3} \mathrm{I}^{3}\right.$, Cornell 49-242 (Co-2), $\mathrm{H} 1\left(\mathrm{Co}-3^{5}\right), \mathrm{K} 23(\mathrm{Co}-5)$ and SEL $1360\left(\mathrm{Co}-5^{2}\right)$ (Table 3$)$.

The SY20 marker was specific for the Co-4 locus, however, this marker did not discriminate the different alleles of this locus, amplifying DNA fragments only for TO ( $\mathrm{Co}$ 4), SEL $1308\left(\mathrm{Co}^{2} \mathrm{4}^{2}\right), \mathrm{K} 10\left(\mathrm{Co}^{3} 3^{4}, \mathrm{Co}-4^{2}, \mathrm{Co}-5\right.$ and $\left.\mathrm{Co}-6\right), \mathrm{K} 13\left(\mathrm{Co}_{-} 4^{2}\right), \mathrm{PI} 207262\left(\mathrm{Co}^{3} 3^{3}\right.$ and $\left.\mathrm{Co}-4^{3}\right)$ and $\mathrm{G} 2333\left(\mathrm{Co}-3^{5}, \mathrm{Co}-4^{2}\right.$ and $\left.\mathrm{Co}-5\right)$ (Table 3). Beraldo et al. (2009) also reported the specificity of the SY20 marker for the Co-4 locus. When screening 42 parents and 76 elite lines developed by the common bean breeding program of the Instituto Agronômico de Campinas (IAC, Campinas, SP, Brazil) with SY20, those authors reported that only the genotype $\mathrm{G} 2333$ ( $\mathrm{Co}-3^{5}, \mathrm{Co}-4^{2}$ and $\left.\mathrm{Co}-5\right)$ showed the expected DNA product associated with the anthracnose resistance allele $\mathrm{Co}-4^{2}$.

The SAS13 marker, identified as linked to $\mathrm{Co}-4^{2}$ allele (Young et al., 1998; Kelly et al., 2003), was specific for the $C o-4$ locus since it amplified only DNA samples from SEL $1308\left(\mathrm{Co}^{2} \mathbf{4}^{2}\right), \mathrm{K} 13\left(\mathrm{Co}^{-2}\right), \mathrm{K} 10\left(\mathrm{Co}-3^{4}, \mathrm{Co}-4^{2}, \mathrm{Co}-5\right.$ and $\left.\mathrm{Co}-6\right), \mathrm{G} 2333\left(\mathrm{Co}-3^{5}, \mathrm{Co}-4^{2}\right.$ and $\mathrm{Co}-5)$ and PI 207262 ( $\mathrm{Co}-3^{3}$ and $\left.\mathrm{Co}-4^{2}\right)$. However, it was shown to be non-specific to $\mathrm{Co}-4^{2}$ allele when amplifying a DNA product in PI 207262 harboring the Co-4 $4^{3}$ allele (Table 3). Awale and Kelly (2001) and Alzate-Marin et al. (2007) already reported that the SAS13 marker amplifies different alleles of the Co-4 locus.

DNA samples from eight genotypes were amplified by the SAB03 marker linked to the Co-5 gene (Vallejo and Kelly, 2001; Campa et al., 2005): BRS Campeiro, BRS Esplendor, BRS Supremo, and CNFC 15875, whose the anthracnose resistance genes have not been characterized yet, and $\mathrm{K} 10\left(\mathrm{Co}_{-} 3^{4}, \mathrm{Co}-4^{2}, \mathrm{Co}-5\right.$ and $\left.\mathrm{Co}-6\right), \mathrm{K} 23(\mathrm{Co}-5), \mathrm{G} 2333$ $\left(\mathrm{Co}-3^{5}, \mathrm{Co}-4^{2}\right.$ and $\left.\mathrm{Co}-5\right), \mathrm{TU}(\mathrm{Co}-5)$ and SEL $1360\left(\mathrm{Co}-5^{2}\right)$, confirming the presence of the Co-5 gene. In this case, SAB03 did not discriminate different alleles of the $\mathrm{Co}-5$ locus (Table 3).

In addition to AB136, the original source of $\mathrm{Co}-6$ gene, only line $\mathrm{K} 10\left(\mathrm{Co}-3^{4}, \mathrm{Co}\right.$ $4^{2}, \mathrm{Co}-5$ and $\left.\mathrm{Co}-6\right)$ presented DNA products amplified with the SAZ20 marker linked to the Co-6 gene (Kelly et al., 2003; Queiroz et al., 2004) (Table 3). Three elite lines were highlighted by the molecular characterization: $\mathrm{K} 10\left(\mathrm{Co}_{-} 3^{4}, \mathrm{Co}_{-} 4^{2}, \mathrm{Co}-5\right.$ and $\left.\mathrm{Co}-6\right)$, presenting the markers SF10, SY20, SAS13, SAB03 and SAZ20, K13 (Co-42), presenting the markers SY20 and SAS13, and K23 (Co-5), presenting the markers SF10 and SAB03. In the field inoculation screening, these three genotypes were also resistant to anthracnose, with emphasis on K10 and K13, since both had a mean severity score of 1.0 (Table 3). 
Table 3. Anthracnose severity for common bean genotypes tested in a field inoculation trial (Santo Antônio de Goiás, GO, Brazil) and molecular screening of those genotypes with SCAR markers linked to anthracnose resistance genes important in Brazil.

\begin{tabular}{|c|c|c|c|c|c|c|c|c|c|c|}
\hline \multirow{2}{*}{ Genotype } & \multirow{2}{*}{ Resistance gene } & \multirow{2}{*}{$\begin{array}{l}\text { Gene } \\
\text { pool }^{\text {a }}\end{array}$} & \multirow{2}{*}{$\begin{array}{l}\text { Market } \\
\text { class }\end{array}$} & \multirow{2}{*}{$\begin{array}{c}\text { Mean } \\
\text { severity }^{\mathrm{b}}\end{array}$} & \multicolumn{6}{|c|}{ SCAR marker ${ }^{c}$} \\
\hline & & & & & $\begin{array}{l}\text { SF10/ } \\
\mathrm{Co}^{-3} 3^{4}\end{array}$ & $\begin{array}{c}\text { SY20/ } \\
\mathrm{Co}-4\end{array}$ & $\begin{array}{l}\text { SH18/ } \\
\mathrm{Co}^{-} 4^{2}\end{array}$ & $\begin{array}{c}\text { SAS13/ } \\
\mathrm{Co}-4^{2}\end{array}$ & $\begin{array}{c}\text { SAB03/ } \\
\text { Co-5 }\end{array}$ & $\begin{array}{c}\text { SAZ20/ } \\
\text { Co-6 }\end{array}$ \\
\hline Ouro Negro & $\mathrm{Co}-3^{4}$ & MA & Black & $1.00 \mathrm{a}$ & 1 & 0 & 0 & 0 & 0 & 0 \\
\hline то & $\mathrm{Co}-4$ & MA & Carioca & $1.00 \mathrm{a}$ & 0 & 1 & 0 & 0 & 0 & 0 \\
\hline SEL 1308 & $\mathrm{Co}-4^{2}$ & MA & Black & $1.00 \mathrm{a}$ & 0 & 1 & 1 & 1 & 0 & 0 \\
\hline K13 & $\mathrm{Co}-4^{2}$ & MA & Carioca & $1.00 \mathrm{a}$ & 0 & 1 & 1 & 1 & 0 & 0 \\
\hline K10 & 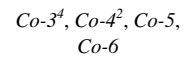 & MA & Carioca & $1.00 \mathrm{a}$ & 1 & 1 & 0 & 1 & 1 & 1 \\
\hline AB 136 & Co-6, $\mathrm{co}-8$ & MA & Red & $1.00 \mathrm{a}$ & 1 & 0 & 0 & 0 & 0 & 1 \\
\hline BRS Esteio & & MA & Black & $1.00 \mathrm{a}$ & 1 & 0 & 0 & 0 & 0 & 0 \\
\hline BRSMG Realce & & A & Rajado & $1.00 \mathrm{a}$ & 1 & 0 & 0 & 0 & 0 & 0 \\
\hline BRS Sublime & & MA & Carioca & $1.00 \mathrm{a}$ & 1 & 0 & 0 & 0 & 0 & 0 \\
\hline CNFC 10729 & & MA & Carioca & $1.00 \mathrm{a}$ & 1 & 0 & 0 & 0 & 0 & 0 \\
\hline Kaboon & $\mathrm{Co}-\mathrm{I}^{2}$ & A & Brown & $1.33 \mathrm{a}$ & 1 & 0 & 0 & 0 & 0 & 0 \\
\hline G 2333 & $\mathrm{Co}-3^{5}, \mathrm{Co}-4^{2}, \mathrm{Co}-5$ & MA & Red & $1.33 \mathrm{a}$ & 1 & 1 & 0 & 1 & 1 & 0 \\
\hline Jalo Vermelho & Co- 12 & A & Jalo & $1.33 \mathrm{a}$ & 0 & 0 & 0 & 0 & 0 & 0 \\
\hline BRS Embaixador & & A & DRK & $1.33 \mathrm{a}$ & 0 & 0 & 0 & 0 & 0 & 0 \\
\hline BRS Estilo & & MA & Carioca & $1.33 \mathrm{a}$ & 1 & 0 & 0 & 0 & 0 & 0 \\
\hline PI 207262 & $\mathrm{Co}-3^{3}, \mathrm{Co}-4^{3}$ & MA & Light brown & $1.67 \mathrm{~b}$ & 1 & 1 & 0 & 1 & 0 & 0 \\
\hline Jalo Listras Pretas & Co-13 & A & Jalo & $1.67 \mathrm{~b}$ & 0 & 0 & 0 & 0 & 0 & 0 \\
\hline BRS Radiante & & A & Rajado & $1.67 \mathrm{~b}$ & 1 & 0 & 0 & 0 & 0 & 0 \\
\hline MDRK & Co- 1 & A & Red & $2.00 \mathrm{~b}$ & 0 & 0 & 0 & 0 & 0 & 0 \\
\hline Perry Marrow & $\mathrm{Co}-1^{3}$ & A & Brown & $2.00 \mathrm{~b}$ & 1 & 0 & 0 & 0 & 0 & 0 \\
\hline AND 277 & $\mathrm{Co}-\mathrm{I}^{4}$ & A & Red & $2.00 \mathrm{~b}$ & 0 & 0 & 0 & 0 & 0 & 0 \\
\hline Widusa & $\mathrm{Co}-\mathrm{I}^{5}$ & MA & Calima & $2.00 \mathrm{~b}$ & 0 & 0 & 0 & 0 & 0 & 0 \\
\hline $\mathrm{TU}$ & $\mathrm{Co}-5$ & MA & Black & $2.00 \mathrm{~b}$ & 1 & 0 & 0 & 0 & 1 & 0 \\
\hline BRS Supremo & & MA & Black & $2.00 \mathrm{~b}$ & 1 & 0 & 0 & 0 & 1 & 0 \\
\hline BRS Executivo & & A & Sugar bean & $2.33 \mathrm{~b}$ & 0 & 0 & 0 & 0 & 0 & 0 \\
\hline BRS Notável & & MA & Carioca & $2.33 \mathrm{~b}$ & 0 & 0 & 0 & 0 & 0 & 0 \\
\hline Mexico 222 & $\mathrm{Co}-3$ & MA & White & $3.00 \mathrm{c}$ & 1 & 0 & 0 & 0 & 0 & 0 \\
\hline K23 & $\mathrm{Co}-5$ & MA & Carioca & $3.33 \mathrm{c}$ & 1 & 0 & 0 & 0 & 1 & 0 \\
\hline BRS Esplendor & & MA & Black & $4.67 \mathrm{~d}$ & 1 & 0 & 0 & 0 & 1 & 0 \\
\hline CNFP 10120 & & MA & Black & $4.67 \mathrm{~d}$ & 1 & 0 & 0 & 0 & 0 & 0 \\
\hline IAC Alvorada & & MA & Carioca & $4.67 \mathrm{~d}$ & 1 & 0 & 0 & 0 & 0 & 0 \\
\hline Pérola & & MA & Carioca & $5.00 \mathrm{~d}$ & 0 & 0 & 0 & 0 & 0 & 0 \\
\hline CNFP 15330 & & MA & Black & $5.33 \mathrm{~d}$ & 0 & 0 & 0 & 0 & 0 & 0 \\
\hline Jalo Precoce & & A & Jalo & $5.33 \mathrm{~d}$ & 0 & 0 & 0 & 0 & 0 & 0 \\
\hline SEL 1360 & $\mathrm{Co}-5^{2}$ & MA & Black & $5.67 \mathrm{~d}$ & 1 & 0 & 0 & 0 & 1 & 0 \\
\hline
\end{tabular}




\begin{tabular}{|c|c|c|c|c|c|c|c|c|c|c|}
\hline \multirow[t]{2}{*}{ Genotype } & \multirow[t]{2}{*}{ Resistance gene } & \multirow[t]{2}{*}{$\begin{array}{l}\text { Gene } \\
\text { pool }^{\mathrm{a}}\end{array}$} & \multirow[t]{2}{*}{$\begin{array}{c}\text { Market } \\
\text { class }\end{array}$} & \multirow{2}{*}{$\begin{array}{c}\text { Mean } \\
\text { severity }^{b}\end{array}$} & \multicolumn{6}{|c|}{ SCAR marker ${ }^{\mathrm{c}}$} \\
\hline & & & & & $\begin{array}{l}\text { SF10/ } \\
\mathrm{Co}-3^{4}\end{array}$ & $\begin{array}{c}\text { SY20/ } \\
\text { Co-4 }\end{array}$ & $\begin{array}{c}\text { SH18/ } \\
\mathrm{Co}-4^{2} \\
\end{array}$ & $\begin{array}{c}\text { SAS13/ } \\
{\text { Co }-4^{2}}^{2}\end{array}$ & $\begin{array}{c}\text { SAB03/ } \\
\text { Co-5 }\end{array}$ & $\begin{array}{c}\text { SAZ20/ } \\
\text { Co-6 }\end{array}$ \\
\hline CNFP 10794 & & MA & Black & $5.67 \mathrm{~d}$ & 0 & 0 & 0 & 0 & 0 & 0 \\
\hline Rudá & & MA & Carioca & $5.67 \mathrm{~d}$ & 0 & 0 & 0 & 0 & 0 & 0 \\
\hline BRS Requinte & & MA & Carioca & $6.00 \mathrm{~d}$ & 0 & 0 & 0 & 0 & 0 & 0 \\
\hline BRSMG Majestoso & & MA & Carioca & $6.00 \mathrm{~d}$ & 1 & 0 & 0 & 0 & 0 & 0 \\
\hline BRS Grafite & & MA & Black & $6.33 \mathrm{e}$ & 1 & 0 & 0 & 0 & 0 & 0 \\
\hline IPR Uirapuru & & MA & Black & $6.33 \mathrm{e}$ & 1 & 0 & 0 & 0 & 0 & 0 \\
\hline BRS Pitanga & & MA & Purple & $6.67 \mathrm{e}$ & 1 & 0 & 0 & 0 & 0 & 0 \\
\hline BRS Agreste & & MA & Mulatinho & $6.67 \mathrm{e}$ & 1 & 0 & 0 & 0 & 0 & 0 \\
\hline BRS Valente & & MA & Black & $7.00 \mathrm{e}$ & 1 & 0 & 0 & 0 & 0 & 0 \\
\hline BRSMG Talismã & & MA & Carioca & $7.00 \mathrm{e}$ & 1 & 0 & 0 & 0 & 0 & 0 \\
\hline BRS FC104 & & MA & Carioca & $7.00 \mathrm{e}$ & 0 & 0 & 0 & 0 & 0 & 0 \\
\hline Cornell 49-242 & $\mathrm{Co}-2$ & MA & Black & $7.33 \mathrm{e}$ & 1 & 0 & 0 & 0 & 0 & 0 \\
\hline Michelite & Co- 11 & MA & White & $7.33 \mathrm{e}$ & 0 & 0 & 0 & 0 & 0 & 0 \\
\hline BRS Campeiro & & MA & Black & $7.33 \mathrm{e}$ & 1 & 0 & 0 & 0 & 1 & 0 \\
\hline CNFC 15873 & & MA & Carioca & $7.33 \mathrm{e}$ & 0 & 0 & 0 & 0 & 0 & 0 \\
\hline BAT 93 & $\mathrm{Co}-3^{3}$ & MA & Mulatinho & $7.67 \mathrm{f}$ & 1 & 0 & 0 & 0 & 0 & 0 \\
\hline BRSMG Madrepérola & & MA & Carioca & $8.00 \mathrm{f}$ & 0 & 0 & 0 & 0 & 0 & 0 \\
\hline CNFC 15875 & & MA & Carioca & $8.00 \mathrm{f}$ & 0 & 0 & 0 & 0 & 1 & 0 \\
\hline Rosinha G2 ${ }^{d}$ & & MA & Small Pink & $9.00 \mathrm{f}$ & 0 & 0 & 0 & 0 & 0 & 0 \\
\hline
\end{tabular}

$\bar{a}$ Andean (A) and Mesoamerican (MA) gene pools. ${ }^{\mathrm{b}}$ Mean scores of disease severity based on a 1-to-9 scale, where resistance reaction $\leq 3.5(1=$ no symptoms and $9=$ dead plants); all plots were inoculated with a mix of the $C$. lindemuthianum races 65 (isolate $\mathrm{Cl}$ 1614), 73 (isolate $\mathrm{Cl} \_1143$ ), 81 (isolate $\mathrm{Cl}$ _1164), 91 (isolate Cl_1247), 475 (isolate Cl_1322), and 1609 (isolate Cl_1294). ${ }^{\mathrm{c}}$ Presence (1) or absence (0) of SCAR marker.

${ }^{\mathrm{d}}$ Susceptible control variety.

According to Kelly et al. (2003), the greater the number of anthracnose resistance alleles present in the same common bean genotype, the greater will be the durability and the efficiency of this resistance. Souza et al. (2014) reported that cultivars or elite lines harboring the alleles $\mathrm{Co}-4^{2}, \mathrm{Co}-5$ and $\mathrm{Co}-6$, individually or in combination (pyramiding), are those with the highest resistance spectrum to anthracnose in Brazil.

Phenotypic and molecular characterization of candidate resistance sources to common bean anthracnose based on their disease reaction in field inoculation trials and on analysis with molecular markers linked to resistance genes has shown to be a useful strategy. It supports the selection of donor parents and resistant lines to be preferably explored by common bean breeding programs in Brazil.

As previously suggested by Souza et al. (2014), the use of the resistant alleles from Mesoamerican gene pool Co- $3^{4}$ (Ouro Negro), Co-4² (SEL 1308 and K13), Co-5 (TU and $\mathrm{K} 23$ ), and $\mathrm{Co}-6$ (AB 136), in combination, as in $\mathrm{K} 10\left(\mathrm{Co}^{4} \mathrm{3}^{4} \mathrm{Co}-4^{2}, \mathrm{Co}-5\right.$ and $\left.\mathrm{Co}-6\right)$, but preferably with alleles from the Andean gene pool, such as $\mathrm{Co}-1, \mathrm{Co}-13$ and others not characterized yet, such as that present in BRSMG Realce (Co-?), should be prioritized by the common bean breeding programs aiming to develop cultivars and elite lines with high 
spectrum and durable resistance to anthracnose. Four of the six SCAR markers tested in the present work (SH18 and SAS13 for $\mathrm{Co}_{-} 4^{2}, \mathrm{SAB} 03$ for $\mathrm{Co}-5$, and SAZ20 for $\mathrm{Co}-6$ ), have shown to be useful for assisted selection of the target resistant genes. This is because these markers were specific for the loci to which they are linked, although they did not discriminate alleles from the same locus, except for SH18, which was shown to be specifically linked to $\mathrm{Co}-4^{2}$.

\section{ACKNOWLEDGMENTS}

The authors are thankful to the Universidade Federal de Minas Gerais (UFMG, Montes Claros, MG, Brazil), Universidade Federal de Goiás (UFG, Goiânia, GO, Brazil) and Embrapa Arroz e Feijão (Santo Antônio de Goiás, GO, Brazil) for the opportunity to develop this research, in addition to their technical and logistic support. This work was financially supported by Embrapa (Brazilian Agricultural Research Corporation - Grant No. 02.14.01.003.00) and by CNPq (Brazilian Council for Scientific and Technological Development - Grant No. 474534/2013-8). L.C. Melo, H.S. Pereira and T.L.P.O. Souza were supported by CNPq.

\section{REFERENCES}

Alzate-Marin AL and Sartorato A (2004). Analysis of the pathogenic variability of Colletotrichum lindemuthianum in Brazil. Annu. Rep. Bean Improv. Coop. 47: 241-242.

Alzate-Marin AL, Baía GS, Paula-Júnior TJ, Carvalho GA, et al. (1997). Inheritance of anthracnose resistance in common bean differential cultivar AB 136. Plant Dis. 81: 996-998.

Alzate-Marín AL, Souza KA, Silva MGM, Oliveira EJ, et al. (2007). Genetic characterization of anthracnose resistance genes $\mathrm{Co}-4^{3}$ and $\mathrm{Co}-9$ in common bean cultivar Tlalnepantla 64 (PI 207262). Euphytica 154: 1-8.

Awale HE and Kelly JD (2001). Development of SCAR markers linked to Co-4 ${ }^{2}$ gene in common bean. Annu. Rep. Bean Improv. Coop. 44: 19-120.

Balardin RS, Jarosz MA and Kelly JD (1997). Virulence and molecular diversity in Colletotrichum lindemuthianum from South, Central, and North America. Phytopathol. 87: 1184-1191.

Bean Improvement Cooperative (2018). BIC genetics committee. Bean Improvement Cooperative, Prosser. Available at <http://www.bic.uprm.edu/?page_id=91>. Assessed 28 May 2018.

Beraldo ALA, Colombo CA, Chiorato AF, Ito MF and Carbonell SAM (2009). Aplicação de marcadores SCARs para seleção de linhagens resistentes à antracnose em feijoeiro. Bragantia 68: 53-61.

Broughton WJ, Hernández G, Blair M, Beebe S, et al. (2003). Beans (Phaseolus spp.) - model food legumes. Plant and Soil 252: 55-128.

Campa A, Giraldez R and Ferreira JJ (2009). Genetic dissection of the resistance to nine anthracnose races in the common bean differential cultivars MDRK and TU. Theor. Appl. Genet. 119: 1-11.

Campa A, Rodriguez-Suárez C, Pañeda A, Giraldez R and Ferreira JJ (2005). The bean anthracnose resistance gene Co-5 is located in linkage group B7. Annu. Rep. Bean Improv. Coop. 48: 68-69.

Carbonell SM, Ito MF, Pompeu AS, Francisco F, et al. (1999). Raças fisiológicas de Colletotrichum lindemuthianum e reação de cultivares e linhagens de feijoeiro no Estado de São Paulo. Fitopatol. Bras. 24: 60-65.

Cruz CD (2013). GENES - a software package for analysis in experimental statistics and quantitative genetics. Acta Sci., Agron. 35: 271-276.

Davide LMC and Souza EA (2009). Pathogenic variability within race 65 of Colletotrichum lindemuthianum and its implications for common bean breeding. Crop Breed. Appl. Biot. 9: 23-30.

Del Peloso MJ and Melo LC (2005). Potencial de rendimento da cultura do feijoeiro comum. Embrapa Arroz e Feijão, Santo Antônio de Goiás, 131 p.

Embrapa Arroz e Feijão (2018). Dados conjunturais da produção de feijão-comum (Phaseolus vulgaris L.) e caupi [Vigna unguiculata (L.) Walp] no Brasil (1985 a 2016): área, produção e rendimento. Embrapa Arroz e Feijão, Santo Antônio de Goiás. Available at <http://www.cnpaf.embrapa.br/socioeconomia/index.htm>. Assessed 28 May 2018.

Ferreira ME and Grattapaglia D (1998). Introdução ao uso de marcadores moleculares em análise genética. $3^{\text {rd }}$ ed, Embrapa Recursos Genéticos e Biotecnologia, Brasília, 220 p. 
Geffroy V, Sévignac M, Billant P, Dron M and Langin T (2008). Resistance to Colletotrichum lindemuthianum in Phaseolus vulgaris: a case study for mapping two independent genes. Theor. Appl. Genet. 116: 407-415.

Gonçalves-Vidigal MC and Kelly JD (2006). Inheritance of anthracnose resistance in the common bean cultivar Widusa. Euphytica 151: 411-419.

Gonçalves-Vidigal MC, Cruz AS, Lacanallo GF, Vidigal Filho PS, et al. (2013). Co-segregation analysis and mapping of the anthracnose Co-10 and angular leaf spot Phg-ON disease-resistance genes in the common bean cultivar Ouro Negro. Theor. Appl. Genet. 126: 2245-2255.

Gonçalves-Vidigal MC, Vidigal Filho PS, Medeiros AF and Pastor-Corrales MA (2009). Common bean landrace Jalo Listras Pretas in the source of a new Andean anthracnose resistance gene. Crop Sci. 49: 133-138.

Ishikawa FH, Ramalho MAP and Souza EA (2011). Common bean lines as potential differential cultivars for race 65 of Colletotrichum lindemuthianum. J. Plant Pathol. 93: 461-464.

Kelly JD and Vallejo AV (2004). A comprehensive review of the major genes conditions resistance to anthracnose in common bean. HortScience 39: 1196-1207.

Kelly JD and Young RA (1996). Proposed symbols for anthracnose resistance genes. Annu. Rep. Bean Improv. Coop. 39: 20-24.

Kelly JD, Gepts P, Miklas PN and Coyne DP (2003). Tagging and mapping of genes and QTL and molecular markerassisted selection for traits of economic importance in bean and cowpea. Field Crops Res. 82: 135-154.

Melo LC (2009). Procedimentos para condução de experimentos de valor de cultivo e uso em feijoeiro comum. Embrapa Arroz e Feijão, Santo Antônio de Goiás, 104 p.

Méndez-Vigo B, Rodriguez-Suárez C, Pañeda A, Ferreira JJ and Giraldez R (2005). Molecular markers and allelic relationships of anthracnose resistance gene cluster B4 in common bean. Euphytica 141: 237-245.

Muhalet CS, Adams MW, Saettler AW and Ghaderi A (1981). Genetic system for the reaction of field beans to beta, gamma, and delta races of Colletotrichum lindemuthianum. J. Am. Soc. Hortic. Sci. 106: 601-604.

Oblessuc PR, Francisco C and Melotto M (2015). The Co-4 locus on chromosome Pv08 contains a unique cluster of 18 COK-4 genes and is regulated by immune response in common bean. Theor. Appl. Genet. 128: 1193-1208.

Pastor-Corrales MA, Otoya MM, Molina A and Singh SP (1995). Resistance to Colletotrichum lindemuthianum isolates from Middle American and Andean South America in different common bean races. Plant Dis. 79: 63-67.

Paula-Júnior TJ and Zambolim L (1998). Doenças. In: Vieira C, Paula-Júnior TJ and Borém A (eds) Feijão: aspectos gerais e cultura no estado de Minas Gerais. Universidade Federal de Viçosa, Viçosa, p. 375-433.

Queiroz VT, Sousa CS, Costa MR, Sanglard DA, et al. (2004). Development of SCAR markers linked to common bean anthracnose resistance genes Co-4 and Co-6. Annu. Rep. Bean Improv. Coop. 47: 249-250.

Rava C, Purchio A and Sartorato A (1994). Caracterização de patótipos de Colletotrichum lindemuthianum que ocorrem em algumas regiões produtoras de feijoeiro comum. Fitopatol. Bras. 19: 167-172.

Ribeiro T, Esteves JAF, Silva DA, Gonçalves JGR, et al. (2016). Classification of Colletotrichum lindemuthianum races in differential cultivars of common bean. Acta Sci., Agron. 38: 179-184.

Rodríguez-Suárez C, Ferreira JJ, Campa A, Pañeda A and Giradles R (2008). Molecular mapping and intra-cluster recombination between anthracnose race-specific resistance genes in the common bean differential cultivars Mexico 222 and Widusa. Theor. Appl. Genet. 116: 807-814.

Singh SP and Schwartz HF (2010). Breeding common bean for resistance to diseases: a review. Crop Sci. 50: 21992223.

Souza TLPO, Ragagnin VA, Melo CLP, Arruda KMA, et al. (2005). Phenotypic and molecular characterization of cultivar BRSMG-Talismã regarding the principal common bean pathogens. Crop Breed. Appl. Biot. 5: 247-252.

Souza TLPO, Wendland A, Rodrigues MS, Almeida LCS, et al. (2014). Anthracnose resistance sources to be explored by the common bean breeding programs in Brazil. Annu. Rep. Bean Improv. Coop. 57: 217-218.

Vallejo V and Kelly J (2001). Development of a SCAR marker linked to Co-5 gene in common bean. Annu. Rep. Bean Improv. Coop. 44: 121-122.

Vallejo V and Kelly JD (2009). New insights into the anthracnose resistance of common bean landrace G2333. Open Horticult. J. 2: 29-33.

Young R, Meloto M, Nodari RO and Kelly JD (1998). Marker-assisted dissection of the oligogenic anthracnose resistence in the common bean cultivar 'G2333'. Theor. Appl. Genet. 96: 87-94.

Zuiderveen GH, Padder BA, Kamfwa K, Song Q and Kelly JD (2016). Genome-wide association study of anthracnose resistance in Andean beans (Phaseolus vulgaris). PloS One 11: e0156391. 